\title{
SEROPREVALENCE AND ENTOMOLOGICAL STUDY ON CHIKUNGUNYA VIRUS AT THE CROATIAN LITTORAL
}

\author{
TAtJana Vilibic-CaVleK ${ }^{1 * *}$, IVA Pem-Novosel ${ }^{2 \#}$, Bernard Kaic ${ }^{2}$, \\ ANDREA BABIĆ-ERCEG ${ }^{3}$, JASMINA KUCINAR ${ }^{4}$, ANA KLOBUCAR $^{5}$, \\ Alan MEDIC 6 , DJANA PAHOR ${ }^{7}$, KatiJa BARAC-JURETIC ${ }^{8}$ \\ and IRA GJENERO-MARGAN ${ }^{9}$ \\ ${ }^{1}$ Department of Virology, Croatian National Institute of Public Health \\ and School of Medicine University of Zagreb, Zagreb, Croatia \\ ${ }^{2}$ Department of Epidemiology, Croatian National Institute of Public Health, Zagreb, Croatia \\ ${ }^{3}$ Department of Molecular Diagnostic, Croatian National Institute of Public Health, \\ Zagreb, Croatia \\ ${ }^{4}$ Department of Microbiology, Istria County Institute of Public Health, Pula, Croatia \\ ${ }^{5}$ Department of Epidemiology, Institute of Public Health "Dr Andrija Stampar", \\ Zagreb, Croatia \\ ${ }^{6}$ Department of Epidemiology, Zadar County Institute of Public Health, Zadar, Croatia \\ ${ }^{7}$ Department of Epidemiology, Primorje-Gorski Kotar County Institute \\ of Public Health, Rijeka, Croatia \\ ${ }^{8}$ Department of Epidemiology, Split-Dalmatia County Institute of Public Health, \\ Split, Croatia \\ ${ }^{9}$ Department of Epidemiology, University of Applied Health Studies, Zagreb, Croatia
}

(Received: 3 February 2015; accepted: 6 March 2015)

During 2011-2012, a total of 1008 serum samples from randomly selected inhabitants of seven Croatian counties located on the Adriatic Coast were tested for the presence of chikungunya virus (CHIKV) IgG antibodies using indirect immunofluorescence assay.

Nine participants $(0.9 \%)$ from four counties were found to be seropositive to CHIKV. Seroprevalence varied from $0.5 \%$ to $1.8 \%$ between counties. Additionally, a total of 3,699 mosquitoes were captured in 126 localities from August 16 to September 24, 2011. Three mosquito species were found: Ae. albopictus (3010/81.4\%), Cx. pipiens $(688 / 18.6 \%)$ and only one specimen of the Cs. longiareolata. Female mosquitoes $(N=1,748)$ were pooled. All pools tested negative for CHIKV RNA using a real-time RT-PCR.

Keywords: Chikungunya virus, seroprevalence, Croatia, entomology

\# Authors with equal contribution.

* Corresponding author; E-mail: tatjana.vilibic-cavlek@hzjz.hr 


\section{Introduction}

Chikungunya fever is a tropical arboviral disease caused by chikungunya virus (CHIKV) that belongs to the family Togaviridae, genus Alphavirus. Chikungunya is endemic in Africa, Southeast Asia and on the Indian subcontinent [1]. Its global emergence started in 2004. A large outbreak originated in Kenya has rapidly spread throughout numerous islands of the Indian Ocean (20052006), India (2006-2007) and parts of Southeast Asia (2006) [2-5]. After a few years of relative dormancy, CHIKV transmission restarted in 2009 and 2010. Many of these epidemics continued into 2012 [6]. In 2013, the first documented outbreak of CHIKV in the Americas was recorded (Caribbean Islands) [7].

CHIKV is maintained by two different transmission cycles. In Africa, the virus is maintained in a sylvatic cycle between non-human primates as the main reservoirs and different species of forest-dwelling mosquitoes (Aedes, Mansonia, Culex) [8]. In Asia, transmission of CHIKV occurs in an urban cycle involving humans and mosquitoes of the Aedes genus (Ae. aegypti, Ae. albopictus) [9].

In the last three decades, Ae. albopictus has rapidly expanded from Asia and Africa to the Americas and Europe [10, 11]. In Europe, travel-associated cases of chikungunya fever have been continuously recorded [12]. During the summer of 2007, a chikungunya outbreak involving more than 200 cases was reported in the Ravenna Province, north-eastern Italy after virus introduction from India which was the first transmission of chikungunya fever within Europe $[13,14]$. This outbreak raised concern because the vector Ae. albopictus has already been introduced in many European countries, including Albania, Belgium, Bosnia and Herzegovina, France, Greece, Italy, the Netherlands, Serbia, Montenegro, Slovenia, Spain and Switzerland [15]. In addition, in September 2010, autochthonous transmission of CHIKV with two confirmed cases was recorded in the French Riviera [16].

For the first time in Croatia, Ae. albopictus was registered in Zagreb, the capital of Croatia, in October 2004 [17]. From September to October 2005, Ae. albopictus was discovered in several places in the Istria peninsula [18]. Since Italy has been known for many years as a country with a high concentration of Ae. albopictus [19], its spread to Croatia as a neighbouring country was expected. Within two years, additional records of Ae. albopictus presence were made in many Croatian places along the Adriatic Coast [20-21].

We conducted a seroprevalence study on CHIKV among inhabitants of the Croatian counties located on the Adriatic coast and entomologic study for the presence of CHIKV RNA in mosquito samples. 


\section{Materials and Methods}

During 2011-2012, a total of 1008 serum samples were tested for the presence of CHIKV IgG antibodies. The samples were randomly selected from deidentified banks of samples taken from participants aged 3-88 years coming for routine testing at 7 Croatian public health institutes located on the Adriatic Coast. None of them reported symptoms of recent febrile disease. CHIKV IgG antibodies were detected using a commercial indirect immunofluorescence assay (AntiChikungunya virus IgG IIFT, Euroimmun, Lübeck, Germany). IgG titer $\geq 10$ was considered positive. Reactive samples were further tested for CHIKV IgM antibodies (Anti-Chikungunya virus IgM IIFT, Euroimmun, Lübeck, Germany) as well as for potential cross-reactivity with dengue virus (DENV; Anti-Dengue virus IgG ELISA, Euroimmun, Lübeck, Germany) and West Nile virus (WNV; Anti-West Nile virus IgG ELISA, Euroimmun, Lübeck, Germany).

In addition, entomologic investigation was performed from August 16 to September 24, 2011, in the period of the highest mosquito activity. A total of 3,699 mosquitoes were captured at 126 locations along the entire Adriatic Coast. Sampling was carried out using Biogents Sentinel traps baited with the standard BG-Lure attractant. Collected mosquitoes were separated by species and gender. Female mosquitoes $(N=1,748)$ were pooled ( 46 pools of up to 40 specimens) and analyzed for CHIKV RNA using a qualitative real-time reverse transcriptasepolymerase chain reaction (RT-PCR). For nucleic acid isolation, an automated system QIAxtractor (QIAGEN) was used. Real-time RT-PCR was performed using a single-tube RT-PCR kit according to the manufacturer's instructions (Invitrogen SuperScript ${ }^{\mathrm{TM}}{ }^{\mathrm{III}}$ Platinum ${ }^{\circledR}$ One-Step Qualitative Kit). The amplification and detection were performed with 7500 Real Time PCR System machine (Applied Biosystems). Each tube contained a $25-\mu 1$ reaction mixture which included $5 \mu \mathrm{l}$ of isolated RNA, $0.2 \mu \mathrm{M}$ forward primer (CCGAAAGGAAACTTCAAAGCAACT), $0.2 \mu \mathrm{M}$ reverse primer (CAGATGCCCGCCATTATTGAT) and $0.1 \mu \mathrm{M}$ probe (FAM-GGGAGGTGGAGCATG-MGB). The reaction mixtures were exposed to a $30 \mathrm{~min} 50^{\circ} \mathrm{C}$ RT step, a $2 \mathrm{~min}$ of Taq activation at $95{ }^{\circ} \mathrm{C}$ and 50 cycles consisting of $95^{\circ} \mathrm{C}$ for $15 \mathrm{~s}$ and $55^{\circ} \mathrm{C}$ for $32 \mathrm{~s}$.

The study was approved by the Ethics Committee of the Croatian National Institute of Public Health.

\section{Results}

Nine samples $(0.9 \%, 95 \% \mathrm{CI}=0.4-1.7)$ were found positive for CHIKV IgG antibodies. CHIKV IgM antibodies were not documented in any IgG seropositive 
Table I. Prevalence of chikungunya virus IgG antibodies among counties

\begin{tabular}{llll}
\hline County & Tested & \multicolumn{2}{l}{ CHIKV IgG positive } \\
& $N(\%)$ & $95 \% \mathrm{CI}$ \\
\hline Overall & $1008(100)$ & $9(0.9)$ & $0.4-1.7$ \\
Istria & $236(23.4)$ & $4(1.7)$ & $0.5-4.3$ \\
Primorje-Gorski Kotar & $112(11.1)$ & $2(1.8)$ & $0.2-6.3$ \\
Lika-Senj & $99(9.8)$ & 0 & $0.0-3.7$ \\
Zadar & $114(11.4)$ & $2(1.8)$ & $0.2-6.3$ \\
Sibenik-Knin & $108(10.7)$ & 0 & $0.0-3.4$ \\
Split-Dalmatia & $200(19.8)$ & $1(0.5)$ & $0.0-2.8$ \\
Dubrovnik-Neretva & $139(13.8)$ & 0 & $0.0-2.6$ \\
\hline
\end{tabular}

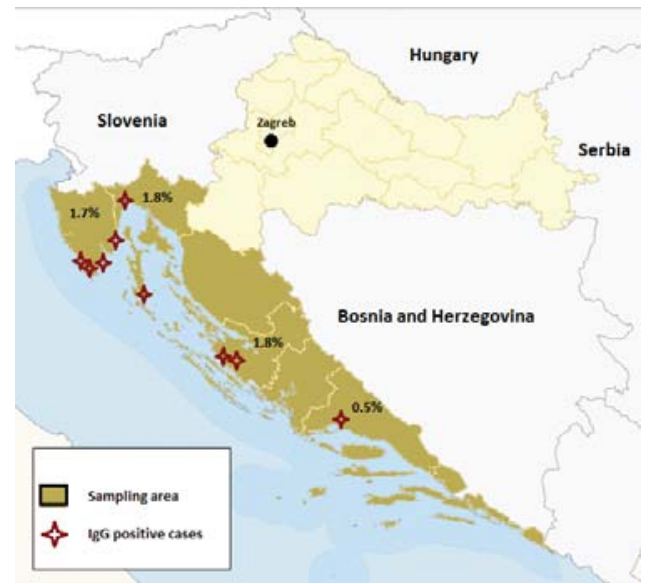

Figure 1. Geographical distribution of chikungunya virus $\operatorname{IgG}$ positive cases

sample. No one sample showed cross-reactive antibodies with DENV and WNV. Five (55.5\%) positive samples were from male and four (45.5\%) from female subjects from four Croatian counties. The median age of seropositive participants was 36.7 years (range $15-77$ years). The seroprevalence varied from $0.5 \%$ to $1.8 \%$ among counties (Table I). Geographical distribution of seropositive cases is presented in Figure 1. Four participants were residents of the Istrian peninsula, two participants were residents of north Croatian coast and Veli Lošinj island while three participants were from Middle Dalmatia.

Entomologic investigation revealed three mosquito species. Out of 3,699 mosquitoes collected, 3010 (81.4\%) were Ae. albopictus, 688 (16.6\%) were Cx. pipiens 
and only one specimen was Cs. longiareolata. All tested mosquito pools were negative for CHIKV RNA.

\section{Discussion}

CHIKV is a re-emerging virus of public health importance causing major outbreaks in Africa and Southeast Asia [2, 4, 7, 22, 23]. In endemic regions, the seroprevalence rates reach $75 \%[5,24]$. With an increase in global travel, the risk for CHIKV spreading outside of endemic areas has heightened. Imported CHIKV infections in travellers have been regularly reported in several European countries [12]. However, autochthonous transmission was documented only in Italy and France $[13,14,16]$. In Europe, there are few published studies on the prevalence of CHIKV. An Italian study conducted in the two neighbouring villages to Emilia-Romagna Region where the outbreak of chikungunya occurred in 2007 showed a prevalence of $10.2 \%$ [25]. An entomological survey carried out on August 21 and 22, 2007 in the same area demonstrated CHIKV RNA in one pool of mosquitoes collected in Castiglione di Ravenna [26]. Moreover, CHIKV antibodies were documented in $1.3 \%$ German aid workers, with the highest seroprevalence reported in those who had resided in Benin (5.7\%) and Thailand $(5.5 \%)$ [27].

In Croatia, autochthonous transmission of some mosquito-borne arboviruses such as dengue virus (2010) [21, 28], West Nile virus (2012-2013) [29, 30] and Usutu virus (2013) [31, 32] has been documented. Seroepidemiological studies on dengue and West Nile virus showed prevalence rates of $0.6 \%$ and $1 \%$, respectively [33]. In addition, CHIKV IgG antibodies were sporadically detected in travellers from endemic areas (data from the National Reference Laboratory for Arboviruses, Croatian National Institute of Public Health). However, there are no data on the seroprevalence of CHIKV. The results of this study showed that $0.9 \%$ of inhabitants of the Croatian littoral have been exposed to this virus. Since autochthonous transmission of chikungunya is not documented in Croatia so far, seropositive persons have most likely been exposed to CHIKV abroad.

The presence of Ae. albopictus is well known for several years along the entire Croatian littoral. Ae. albopictus was the most prevalent mosquito species detected in this study (81.4\%), however, CHIKV RNA was not found in any of the tested pools.

In conclusion, the results of this study indicate a low CHIKV prevalence rate $(0.9 \%)$ among inhabitants of the coastal Croatian region. Although Croatia is not endemic country for CHIKV, current data including recent autochthonous Italian and French CHIKV cases indicate that indigenous transmission of CHIKV 
is possible. Permanent vector control measures should be regularly performed as the risk of chikungunya fever is definitely present, particularly in regions with established Ae. albopictus population.

\section{Acknowledgements}

Authors thank Ljiljana Milasincic and Bruno Todorovic for technical assistance.

\section{Conflict of Interest}

None.

\section{References}

1. Fontenille, D., Failloux, A.B., Romi, R.: Should we expect chikungunya and dengue in Southern Europe? In: Takken, W., Knols, B.G.J. (eds): Emerging Pests and Vector-borne Diseases in Europe. Academic Publishers, Wageningen, 2007, pp. 169-184.

2. Josseran, L., Paquet, C., Zehgnoun, A., Caillere, N., Le Tertre, A., Solet, J.L., Ledrans, M.: Chikungunya disease outbreak, Reunion Island. Emerg Infect Dis 12, 1994-1995 (2006).

3. Charrel, R.N., de Lamballerie, X., Raoult, D.: Chikungunya outbreaks-the globalization of vectorborne diseases. N Engl J Med 356, 769-771 (2007).

4. Mavalankar, D., Shastri, P., Raman, P.: Chikungunya epidemic in India: a major publichealth disaster. Lancet Infect Dis 7, 306-307 (2007).

5. Kumar, N.P., Suresh, A., Vanamail, P., Sabesan, S., Krishnamoorthy, K.G., Mathew, J., Jose, V.T., Jambulingam, P.: Chikungunya virus outbreak in Kerala, India, 2007: a seroprevalence study. Mem Inst Oswaldo Cruz 106(8), 912-916 (2011).

6. Weaver, S.C., Osorio, J.E., Livengood, J.A., Chen, R., Stinchcomb, D.T.: Chikungunya virus and prospects for a vaccine. Expert Rev Vaccines 11(9), 1087-1101 (2012).

7. Van Bortel, W., Dorleans, F., Rosine, J., Blateau, A., Rousset, D., Matheus, S., LeparcGoffart, I., Flusin, O., Prat, C., Cesaire, R., Najioullah, F., Ardillon, V., Balleydier, E., Carvalho, L., Lemaitre, A., Noel, H., Servas, V., Six, C., Zurbaran, M., Leon, L., Guinard, A, van den Kerkhof, J., Henry, M., Fanoy, E., Braks, M., Reimerink, J., Swaan, C., Georges, R., Brooks, L., Freedman, J., Sudre, B., Zeller, H.: Chikungunya outbreak in the Caribbean region, December 2013 to March 2014, and the significance for Europe. Euro Surveill 19(13), pii-20759 (2014).

8. Thiboutot, M.M., Kannan, S., Kawalekar, O.U., Shedlock, D.J., Khan, A.S., Sarangan, G., Srikanth, P., Weiner, D.B., Muthumani, K.: Chikungunya: a potentially emerging epidemic? PLoS Negl Trop Dis 4(4), e623 (2010).

9. Caglioti, C., Lalle, E., Castilletti, C., Carletti, F., Capobianchi, M.R., Bordi, L.: Chikungunya virus infection: an overview. New Microbiol 36(3), 211-227 (2013). 
10. Lambrechts, L., Scott, T.W., Gubler, D.J.: Consequences of the expanding global distribution of Aedes albopictus for dengue virus transmission. PLoS Negl Trop Dis 4(5), e646 (2010).

11. Waldock, J., Chandra, N.L., Lelieveld, J., Proestos, Y., Michael, E., Christophides, G., Parham, P.E.: The role of environmental variables on Aedes albopictus biology and chikungunya epidemiology. Pathog Glob Health 107(5), 224-241 (2013).

12. Odolini, S., Parola, P., Gkrania-Klotsas, E., Caumes, E., Schlagenhauf, P., López-Vélez, R., Burchard, G.D., Santos-O'Connor, F., Weld, L., von Sonnenburg, F., Field, V., de Vries, P., Jensenius, M., Loutan, L., Castelli, F.: Travel-related imported infections in Europe, EuroTravNet 2009. Clin Microbiol Infect 18(5), 468-474 (2012).

13. Rezza, G., Nicoletti, L., Angelini, R., Romi, R., Finarelli, A.C., Panning, M., Cordioli, P., Fortuna, C., Boros, S., Magurano, F., Silvi, G., Angelini, P., Dottori, M., Ciufolini, M.G., Majori, G.C., Cassone, A., CHIKV study group: Infection with chikungunya virus in Italy: an outbreak in a temperate region. Lancet 370(9602), 1840-1846 (2007).

14. Angelini, R., Finarelli, A.C., Angelini, P., Po, C., Petropulacos, K., Macini, P., Fiorentini, C., Fortuna, C., Venturi, G., Romi, R., Majori, G., Nicoletti, L., Rezza, G., Cassone A.: An outbreak of chikungunya fever in the province of Ravenna, Italy. Euro Surveill 12(9), E070906.1 (2007).

15. Depoortere, E., Coulombier, D.: Chikungunya risk assessment for Europe: recommendations for action. Euro Surveill 11(19), pii=2956 (2006).

16. Grandadam, M., Caro, V., Plumet, S., Thiberge, J.M., Souarès, Y., Failloux, A.B., Tolou, H.J., Budelot, M., Cosserat, D., Leparc-Goffart, I., Desprès, P.: Chikungunya virus, Southeastern France. Emerg Infect Dis 17(5), 910-913 (2011).

17. Klobucar, A., Merdic, E., Benic, N., Baklaic, Z., Krcmar, Z.: First record of Aedes albopictus in Croatia. J Am Mosq Control Assoc 22(1), 147-148 (2006).

18. Boca, I., Merdic, E., Landeka, N., Sudaric Bogojevic, M.: Dissemination of Stegomyia albopicta (Skuse 1895) in Istria, Croatia. Entomol Croat 10(1-2), 23-36 (2006). (Article in Croatian)

19. Romi, R., Di Luca, M., Majori, G.: Current status of Aedes albopictus and Aedes atropalpus in Italy. J Am Mosq Control Assoc 15(3), 425-427 (1999).

20. Ferenčić, N., Racz, A.: Presence and spreading of the Asian tiger mosquito Stegomya albopicta (Aedes albopictus) along the western coast and the Istrian inland. Med Jad 40(1-2), 5-10 (2010). (Article in Croatian)

21. Gjenero-Margan, I., Aleraj, B., Krajcar, D., Lesnikar, V., Klobučar, A., Pem-Novosel, I., Kurečić-Filipović, S., Komparak, S., Martić, R., Đuričić, S., Betica-Radić, L., Okmadžić, J., Vilibić-Čavlek, T., Babić-Erceg, A., Turković, B., Avšić-Županc, T., Radić, I., Ljubić, M., Šarac, K, Benić, N., Mlinarić-Galinović, G.: Autochthonous dengue fever in Croatia, August-September 2010. Euro Surveill 16(9), pii-19805 (2010).

22. Mombouli, J.V., Bitsindou, P., Elion, D.O., Grolla, A., Feldmann, H., Niama, F.R, Parra, H.J., Munster, V.J.: Chikungunya virus infection, Brazzaville, Republic of Congo, 2011. Emerg Infect Dis 19(9), 1542-1543 (2013).

23. Wangchuk, S., Chinnawirotpisan, P., Dorji, T., Tobgay, T., Dorji, T., Yoon, I.K., Fernandez, S.: Chikungunya fever outbreak, Bhutan, 2012. Emerg Infect Dis 19(10), 1681-1684 (2013).

24. Sergon, K., Njuguna, C., Kalani, R., Ofula, V., Onyango, C., Konongoi, L.S., Bedno, S., Burke, H., Dumilla, A.M., Konde, J., Njenga, M.K., Sang R., Breiman, R.F.: Seroprevalence of Chikungunya virus (CHIKV) infection on Lamu Island, Kenya, October 2004. Am J Trop Med Hyg 78(2), 333-337 (2008). 
25. Moro, M.L., Gagliotti, C., Silvi, G., Angelini, R., Sambri, V., Rezza, G., Massimiliani, E., Mattivi, A., Grilli, E., Finarelli, A.C., Spataro, N., Pierro, A.M., Seyler, T., Macini, P., Chikungunya Study Group: Chikungunya virus in north-eastern Italy: a seroprevalence study. Am J Trop Med Hyg 82(3), 508-511 (2010).

26. Bonilauri, P., Bellini, R., Calzolari, M., Angelini, R., Venturi, L., Fallacara, F., Cordioli, P., Angelini, P., Venturelli, C., Merialdi, G., Dottori, M.: Chikungunya virus in Aedes albopictus, Italy. Emerg Infect Dis 14(5), 852-854 (2008).

27. Eisenhut, M., Schwarz, T.F., Hegenscheid, B.: Seroprevalence of dengue, chikungunya and Sindbis virus infections in German aid workers. Infection 27(2), 82-85 (1999).

28. Kurolt, I.C., Betica-Radić, L., Đaković-Rode, O., Franco, L., Zelená, H., Tenorio, A., Markotić, A.: Molecular characterization of dengue virus 1 from autochthonous dengue fever cases in Croatia. Clin Microbiol Infect 19(3), E163-165 (2013).

29. Pem-Novosel, I., Vilibic-Cavlek, T., Gjenero-Margan, I., Pandak, N., Peric, Lj., Barbic, Lj., Listes, E., Cvitkovic, A., Stevanovic, V., Savini, G.: First outbreak of West Nile virus neuroinvasive disease in humans, Croatia, 2012. Vector Borne Zoonotic Dis 14(1), 82-84 (2014).

30. Kurolt, I.C., Krajinović, V., Topić, A., Kuzman, I., Baršić, B., Markotić, A.: First molecular analysis of West Nile virus during the 2013 outbreak in Croatia. Virus Res 189, C:6366 (2014).

31. Barbic, Lj., Vilibic-Cavlek, T., Listes, E., Stevanovic, V., Gjenero-Margan, I., LjubinSternak, S., Pem-Novosel, I., Listes, I., Mlinaric-Galinovic, G., Di Gennaro, A., Savini, G: Demonstration of Usutu virus antibodies in horses, Croatia. Vector Borne Zoonotic Dis 13(10), 772-774 (2013).

32. Vilibic-Cavlek, T., Kaic, B., Barbic, Lj., Pem-Novosel, I., Slavic-Vrzic, V., Kurecic-Filipovic, S., Babic-Erceg, A., Listes, E., Stevanovic, V., Gjenero-Margan, I., Savini, G.: First evidence of simultaneous occurrence of West Nile virus and Usutu virus neuroinvasive disease in humans in Croatia during the 2013 outbreak. Infection 42(4), 689-695 (2014).

33. Pem-Novosel, I., Vilibic-Cavlek, T., Gjenero-Margan, I., Kaic, B., Babic-Erceg, A., Merdic, E., Medic, A., Ljubic, M., Pahor, Dj., Erceg, M.: Dengue virus infection in Croatia: seroprevalence and entomological study. New Microbiol 38, 93-96 (2015). 